\title{
The Effect of Graphene Oxide Exfoliation Degree on Graphene Film Properties
}

\section{Grafen Oksit Tabakalanma Derecesinin Grafen Film Özelliklerine Etkisi}

Geliş / Received: 21/03/2021

\author{
Nevin Atalay Gengeç ${ }^{1 *}$
}

Revize / Revised: 15/05/2021

Kabul / Accepted: 17/05/2021

\begin{abstract}
Interest in graphene, which is a new material, is increasing day by day due to its unique mechanical, electrical, and thermal properties. Graphite oxide (GRO), which is synthesized as a result of a series of chemical processes of graphite, was used as the primary material in the production of graphene film. In this study, firstly, graphene oxide (GO) dispersions with different exfoliation degrees were prepared from de-ionized water (DI-water) and repeatedly washed GRO mixture at different ultrasound times. Then, GO films with the same film thickness were produced by casting of the prepared GO dispersions. GO films with different exfoliation degrees were thermally reduced to graphene at $1100{ }^{\circ} \mathrm{C}$, and the change in reduced graphene film (RGO) properties was investigated. $\mathrm{XRD}$, SEM, and FTIR measurements were made for the characterization of thermally reduced graphene and GO films. While the maximum degree of exfoliation was obtained for GO films in 8 hours of ultrasound, the maximum degree of exfoliation was obtained even in 3 hours of ultrasound duruationby thermal reduction of GO films at $1100{ }^{\circ} \mathrm{C}$.
\end{abstract}

Keywords- Graphene, Ultrasound, Thermal Reduction, Casting, Thick Film

ÖZ

Yeni bir material olan grafeneolan ilgi, grafenin eşsiz mekanik, elektriksel ve termal özelliklerinden dolayı gün geçtikçe artmaktadır. Grafen film üretiminde, grafitin bir dizi kimyasal işlemi sonucunda sentezlenen grafitoksit (GRO), temel malzeme olarak kullanılmıştır. Bu çalışmada öncelikle, de-iyonizesu (DI-su) ile tekrar tekrar yıkanmış GRO karışımından farklı ultra ses sürelerinde hazırlanan tabakalanma dereceleri farklı grafen oksit (GO) dispersiyonları hazırlanmıştır. Ardından, hazırlanan GO dispersiyonları ile döküm yoluyla aynı filmm kalınlığında GO filmleri üretilmiştir. Farklı tabakalanma derecesine sahip GO filmler $1100{ }^{\circ} \mathrm{C}$ 'de termal olarak grafene indirgenmiş ve indirgenmiş grafen film özelliklerindeki değişim incelenmiştir. Termal olarak indirgenmiş grafen ve GO filmlerin karakterizasyonu için XRD, SEM ve FTIR ölçümleri yapılmıştır. GO filmleri için 8 saatlik ultra ses süresinde maksimum tabakalanma derecesi elde edilirken, GO filmlerinin $1100{ }^{\circ} \mathrm{C}$ 'de termal olarak indirgenmesi ile 3 saatlik ultra ses süresinde dahi maksimum tabakalanma derecesi elde edilmiştir. 


\section{INTRODUCTION}

Graphene is known as a two-dimensional carbon allotrope nanomaterial, which is considered to be twodimensional because it has a single atom thickness, and has superior properties formed by the perfect arrangement of covalently bonded carbon atoms in a hexagonal honeycomb lattice [1,2]. Graphene was first obtained by Geim and Novoselov in 2004 by separating a single layer from graphite with the help of tape, and Geim and Novoselov received the Nobel Prize in physics in 2010 for revealing the extraordinary and superior properties of graphene [1]. Graphene has many superior electricals, mechanical and thermal properties, such as high surface area $(\sim 2630$ $\mathrm{m}^{2} / \mathrm{g}$ ) and electrical conductivity $(\sim 2000 \mathrm{~S} / \mathrm{cm})$, being 100 times more durable than steel [3]. Due to these superior properties, graphene finds many application areas such as transparent electrodes, transistors, sensors, clean energy devices, nanocomposites, organic photovoltaic devices, and saltwater treatment [4].

Graphene is produced by methods, such as micromechanical separation, exfoliation, epitaxial growth, and chemical vapor deposition (CVD) [5]. These methods often allow the production of expensive and low quantities of graphene. However, graphene synthesis by the chemical method is more preferred because it can be carried out on large scales and ata low cost. The production of graphene by the chemical method is carried out in the following steps: i) obtaining graphite oxide as a result of oxidation of graphite in acid and oxidant environment, ii) obtaining graphene oxide (GO) after the stratification (exfoliation) of graphite oxide (GRO) and iii) reduction of graphene as chemical, thermal or chemical+thermal [6]. The properties of graphene produced by chemical method vary according to acid, oxidant, and reducing species, and therefore many studies have been conducted on GRO synthesis. The most known synthesis method of GRO is the oxidation of graphite with potassium permanganate and sodium nitrate in concentrated sulfuric acid by Hummers and Offeman in 1958 [7]. However, in later studies, it was determined that GRO synthesized by the Hummers method was not fully oxidized [8, 9]. Depending on the method used in GRO production, the defect degree of the graphene obtained, the oxidation degree of the obtained GRO, and the oxygen content after reduction change [10]. Therefore, GRO synthesis has been performed by various researchers using modified Hummers methods [8, 11, 12] and improved Hummers method (i.e. Torr method) [9]. In the Torr method, the oxidation degree of graphite and the obtained GRO yield were increased by using sulfuric acid / phosphoric acid mixture as acid.

GO shows hydrophilic properties because of the hydroxyl and carboxyl groups in its structure, and therefore it can remain in the water and many polar solvents without precipitation for weeks as a result of its stabilization by exfoliation with ultrasonication $[13,14]$. Depending on the change in graphite properties and GRO synthesis methods, the sonication time is different for each GRO mixture, since the obtained GRO is in different oxidation degrees and concentrations, and as the sonication time increases, the obtained GO sheet size decreases. However, excessive sonication times cause the obtained GO to break down and thus to be defected [15]. Also, because stable concentrated GO dispersions at concentrations of $1-5 \mathrm{mg} / \mathrm{mL}$ in water can be prepared, the studies with GO dispersions gained momentum[16-18]. In the literature, GO films with different thicknesses and properties were produced from stable GO dispersions, using methods such as CVD [19], spin coating [20, 21], casting by casting [22-26], and filtration [27]. These GO films with different thicknesses were reduced chemicallyand/or thermally to obtain single-layer (ultra-thin) graphene, thin layer graphene, and multi-layer (thick) graphene films. Depending on the method used in film production, the distance between graphene layers, mechanical properties, and structural properties of graphene change. Graphene films obtained by casting method at the same film thickness show better mechanical properties than those obtained by the filtration method. The distance between the graphene films obtained by casting is greater than those obtained by the filtration method. While there is a tighter and more regular stacking in the filtration method due to the pressure caused by the vacuum, the situation is the opposite as there is no pressure in the casting method [28].

Due to the oxygen groups in the GO structure, it shows insulator property and transforms into graphene or reduced graphene oxide (RGO), which shows conductive property with the reduction of oxygen groups [29]. Different reduction processes give rise to different properties of RGO, which in turn affects the final performance of materials composed of RGO. In the literature, conductive thin films [14, 21], graphene foams [30, 31], graphene sheets [23], and graphene papers [27, 32-35] have been produced by reducing GO to RGO. Thermal reduction of GO to graphene provides a good alternative to the chemical reduction process of graphene. Because thermal reduction has advantages such as simple, environmentally friendly, reduction at all temperatures, and the conductivity of graphene-like materials (such as graphite, GO) that show insulator property [36-38]. Studies have presented that the transformation into the conductive form of obtained RGO by thermal reduction of GO is higher than that obtained by chemical reduction [39]. 
The thickness of graphene films can be changed from monolayer graphene to multilayer graphene according to the graphite oxide production method, concentration, and film-forming method. Thinner films exhibit more graphene-specific properties, while thicker films show semi-metal properties such as graphite [14]. In the literature, graphene in micrometer thickness is generally defined as reduced graphene oxide and it has been determined that graphene films with over 10 layers show graphitic properties [40, 41]. Mechanical properties increase with the increasing film thickness in RGO [28].

This study aims to determine the effect of GO dispersion preparation conditions on reduced graphene film properties in the production of thick graphene films that are cheap and industrially producible. For this purpose, stable GO dispersions were prepared at different ultrasound times than GRO which was systematically washed repeatedly. Thus, the effect of both GO dispersion concentration and ultrasound time on GO film properties was determined. GO films of the same thickness were obtained by casting from $\mathrm{GO}$ dispersions with different amounts and properties and then thermally reduced to RGO. The morphologic and structural properties of GO and RGOfilms were determined by SEM, FTIR, and XRD measurements.

\section{MATERIAL VE METOT}

\section{A. Material}

Graphite $(<20 \mathrm{~m})$ sulfuric acid $\left(\mathrm{H}_{2} \mathrm{SO}_{4}\right)$, phosphoric acid $\left(\mathrm{H}_{3} \mathrm{PO}_{4}\right)$, hydrochloric acid $(\mathrm{HCl})$, ethanol, potassium permanganate $\left(\mathrm{KMnO}_{4}\right)$, hydrogen peroxide $\left(\mathrm{H}_{2} \mathrm{O}_{2}\right)$ chemicals used in $\mathrm{GRO}$ synthesis were purchased from Sigma Aldrich and all It is of high purity and has been used directly. De-ionized water (DI-water; electrical resistance of 18.2 Megaohm-cm) produced in the ultrapure water device was used in the preparation of GO dispersions and all washing processes. In the graphene synthesized processors with the thermally reducing of the GO films, argon gas (99.9999\%) was used and was purchased from Linde Gas Inc. Turkey.

\section{B. Graphite Oxide Synthesis}

Torr method was used in the synthesis of GRO by chemical method from graphite [9]. $720 \mathrm{~mL} \mathrm{H}_{2} \mathrm{SO}_{4}$, $80 \mathrm{~mL} \mathrm{H}_{3} \mathrm{PO} 4,6 \mathrm{~g}$ Graphite, and 36 grams $\mathrm{KMnO}_{4}$ were added into a $1 \mathrm{~L}$ conical flask at $700 \mathrm{rpm}$. At this time, it was observed that the temperature of the mixture was approximately $35-40{ }^{\circ} \mathrm{C}$. The mixture was placed in a water bath so that the mixing process continued and after the temperature was brought to $50{ }^{\circ} \mathrm{C}$, it was kept at 50 ${ }^{\circ} \mathrm{C}$ for 12 hours by stirring. Meanwhile, it was observed that the color of the mixture was brown-gray. At the end of 12 hours, while stirring continued, the heater was turned off and the mixture was allowed to come to room temperature. When the mixture reached room temperature, it was taken into the ice bath by continuing the stirring process and the temperature has waited until the temperature decreased to $0{ }^{\circ} \mathrm{C}$, and then $8 \mathrm{~mL}$ of $30 \% \mathrm{H}_{2} \mathrm{O}_{2}$ was added slowly so that the temperature did not exceed $20^{\circ} \mathrm{C}$. During the addition, it was observed that foam was formed and there was no color change. After the addition of $\mathrm{H}_{2} \mathrm{O}_{2}$, the mixing process was continued and the mixture was left for 1 hour, and then it was centrifuged at $9000 \mathrm{rpm}$ for 15 minutes and the supernatant was discarded. The resulting precipitate was washed twice with DI-water, $30 \% \mathrm{HCl}$ and ethanol, respectively, and centrifuged at $9000 \mathrm{rpm}$ for 15 minutes, and discarded with supernatant. The resulting GRO mixture was washed repeatedly by dialysis until $\mathrm{pH}=5$ to remove acid and salt after centrifugation. The resulting GRO mixture was used as the GRO stock mixture, which was obtained by filling up to $2 \mathrm{~L}$ in a flask (concentration $6 \mathrm{mg} / \mathrm{mL}$ ) and repeatedly washing.

\section{Graphene Oxide Synthesis}

GRO mixture with a concentration of $6 \mathrm{mg} / \mathrm{mL}$ was used in the preparation of stable GO dispersions from GRO. The stock GRO mixture was mixed on the mixer for 10 minutes and an equal amount of $500 \mathrm{~mL}$ was taken into 4 different flasks. Each GRO mix was subjected to ultrasound for 3, 5, 8, and 12 hours, and then centrifuged at $3000 \mathrm{rpm}$ for 30 minutes to prepare stable GO dispersions. The concentration of stable GO dispersions was determined by solids analysis. 


\section{Graphene Oxide and Graphene Film Production}

GO film was prepared by pouring GO dispersions at different concentrations prepared from GRO mixtures into a Teflon cell of $9 \times 10 \mathrm{cmxcm}$ in a way to produce films of the same thickness and drying at 40 ${ }^{\circ} \mathrm{C}$.Proterm brand gas-fed tube furnace was used to thermally reduce the prepared GO films to RGO. GO films were placed between $4 \mathrm{~mm}$ thick quartz glass plates cut as $10 \mathrm{x} 10 \mathrm{cmxcm}$ and placed inside the tube oven. Afterward, the flanges of the tube furnace were closed and the vacuum pump was operated to create a vacuum of 0.550 bar in the environment. When the desired vacuum was reached, Argon gas (high purity Argon 6.0) was fed into the tube furnace at a flow rate of $0.1 \mathrm{~L} / \mathrm{min}$. During the feeding of argon gas, the pressure of the environment reaches a maximum of 0.060 bar thanks to the check valve at the exit end of the tube furnace. This procedure was repeated twice for the complete removal of other gases present in the environment. Then the argon gas was fed for another half an hour and then the heating system of the furnace was switched on. In the thermal reduction process, the furnace temperature was raised to the desired degree $\left(1100^{\circ} \mathrm{C}\right)$, kept at this temperature for 15 minutes, and then the oven was programmed to start cooling. Argon gas was continued to be fed during the cooling phase, and the samples were taken out of the furnace by disconnecting the argon gas supply when the oven interior temperature was at room conditions. The representative scheme for the production of graphene by the chemical method has given in Figure 1.
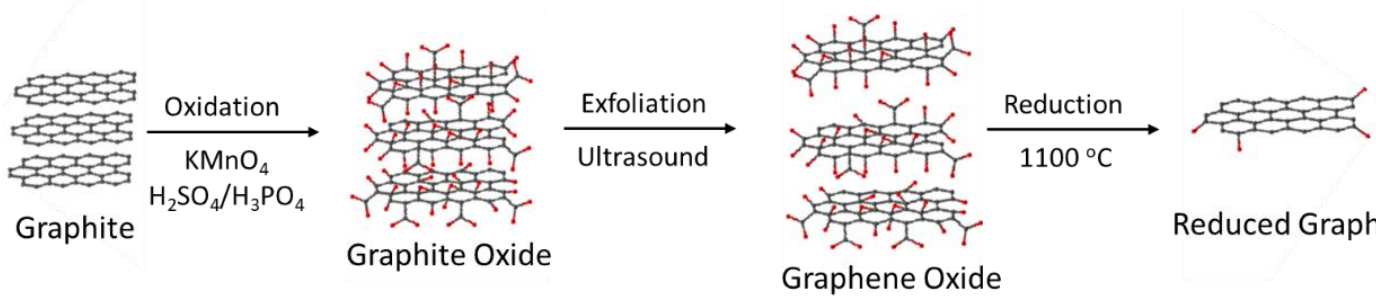

Reduced Graphene Oxide

Graphene Oxide

Figure 1. Representative reaction steps of RGO production by reducing GO, which is chemically produced as a result of the oxidation and exfoliation processes of graphite.

\section{E. Graphene Oxide and Graphene Film Characterization}

X-ray diffraction (XRD) for structural analysis of GO and RGOfilms, FTIR for examining functional groups, and micrometer for film thickness determination. SEM (Scanning Electron Microscope) device was used to determine the surface morphology of GO and RGOfilms. Also, section SEM images were taken to determine the degrees of GO and graphene stratification. To obtain the SEM image of the sections, the films were frozen in liquid nitrogen for about 10 seconds, and then they were broken with the help of tweezers and the SEM image of the broken section was taken.

\section{RESULTS AND DISCUSSION}

In this study, GO films of the same thickness were produced by the casting method from GO dispersions obtained by subjecting GRO, which was synthesized by the chemical method according to the Torr method, to ultrasound at different ultrasound durations. Although the concentrations of GO dispersions prepared in different ultrasound times were different, the amount of GO dispersion that was cast was changed, and GO films of the same thickness were obtained. Thus, the effect of ultrasound duration on GO film properties was determined. The obtained GO films were thermally reduced to RGOat $1100{ }^{\circ} \mathrm{C}$ in an argon gas environment. The changes in the properties of RGOfilms such as thickness and distance between layers were investigated. Results and discussions regarding these findings are presented below within the scope of the article.

\section{A. The effect of Ultrasound Time on Functional and Structural Properties of GO and RGO Films}

FTIR and XRD analyzes were performed to determine the structural and functional groups of GO and RGO films.Figure 2shows the FTIR spectra used to examine the functional groups of GO and RGO films. In the FTIR spectrum, the -OH vibration stress in the region of $3300-3600 \mathrm{~cm}^{-1}$ is from the - $\mathrm{OH}$ and $-\mathrm{COOH}$ groups, the $\mathrm{C}=\mathrm{O}$ vibration stress in the $1700-1720 \mathrm{~cm}^{-1}$ region is from carbonyl or carboxyl groups, the peaks in the 1600 $1620 \mathrm{~cm}^{-1}$ region are from the non-oxidized $\mathrm{C}=\mathrm{C}$ bonds, the presence of $\mathrm{C}-\mathrm{O}-\mathrm{C}$ vibration stresses in the region between $1360-1380 \mathrm{~cm}^{-1}$ is due to the epoxy groups and the presence of carbonyl groups in the $\mathrm{C}-\mathrm{O}$ vibration stresses located in the 1040-1060 $\mathrm{cm}^{-1}$ region [42]. Also, as seen from the FTIR spectra of reduced graphene in 


\begin{tabular}{|c|c|c|}
\hline & $\begin{array}{l}\text { BŞEÜ Fen Bilimleri Dergisi } \\
8(1), 345-355,2021\end{array}$ & $\begin{array}{r}\text { BSEU Journal of Science } \\
\text { https://doi.org/10.35193/bseufbd.900732 }\end{array}$ \\
\hline ERS & & 2458-7575 (https://dergipark.org.tr/tr/pub/bseufbd) \\
\hline
\end{tabular}

Figure 2, with thermal reduction of GO films, all peaks responsible for oxygen functional groups (-OH, $-\mathrm{COOH}$, $\mathrm{C}=\mathrm{O}, \mathrm{CO}, \mathrm{C}-\mathrm{OH}, \mathrm{C}-\mathrm{OC}$ ) disappear, $\mathrm{GO}$ effectively thermal reduced to graphene, and characteristic peaks specific to graphene are formed.As a result, as can be seen from the FTIR spectra obtained for RGO and GO, GO was reduced to RGO even in 3 hours of ultrasound time.

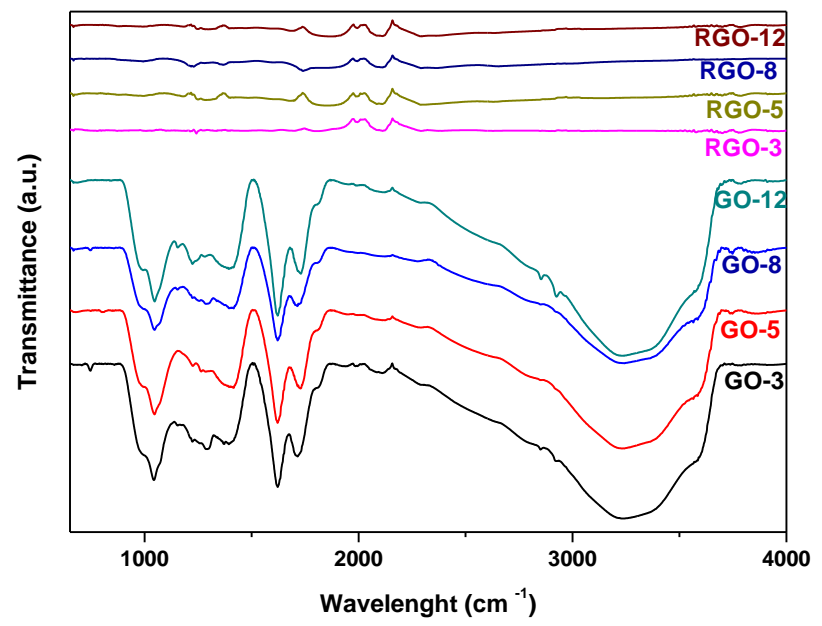

Figure 2. FTIR spectra of GO and reduced graphene films.

Figure 3shows the XRD diffractions taken to determine the structural analysis of graphene oxide and reduced graphene films. According to the XRD diffractions, the characteristic peak of graphene oxide $\left(2 \theta=11^{\circ}\right)$ was found in the spectra of all graphene oxide films, while the characteristic graphene oxide peak for reduced graphene films disappeared and replaced with a graphene-specific characteristic peak around $2 \theta=25^{\circ}[3,43]$. For GO and RGO films, it is seen that the peak intensity increases with the increase of ultrasound time up to 8 hours, that is, the degree of exfoliation increases, but the peak intensity decreases in 12 hours ultrasound time, thus the degree of exfoliation decreases. To explain this situation better, the distance between layers (d) was calculated according to Bragg's equation (Equation 1) and the results obtained in Table 1are given. According to XRD measurements, it was used $n=1$ and $\lambda=1.5$ in Bragg's equation.

$$
\mathrm{n} \lambda=2 \mathrm{~d} \operatorname{Sin}(\theta)
$$

Table 1. Distances between layers calculated from Bragg's equation using XRD results of GO and graphene films.

\begin{tabular}{lccl}
\hline \hline Sample Code & $\begin{array}{c}\text { Ultrasound Time of } \\
\text { GO (hours) }\end{array}$ & $\mathbf{2 \theta}\left(^{\left({ }^{\circ}\right)}\right.$ & $\mathbf{d}(\mathbf{n m})$ \\
\hline \hline GO-3 & 3 & 10.56 & 0.815 \\
\hline GO-5 & 5 & 10.57 & 0.814 \\
\hline GO-8 & 8 & 10.581 & 0.813 \\
\hline GO-12 & 12 & 10.58 & 0.814 \\
\hline RGO-3 & 3 & 26.365 & 0.329 \\
\hline RGO-5 & 5 & 25.963 & 0.334 \\
\hline RGO-8 & 8 & 25.72 & 0.337 \\
\hline RGO-12 & 12 & 25.883 & 0.335 \\
\hline
\end{tabular}




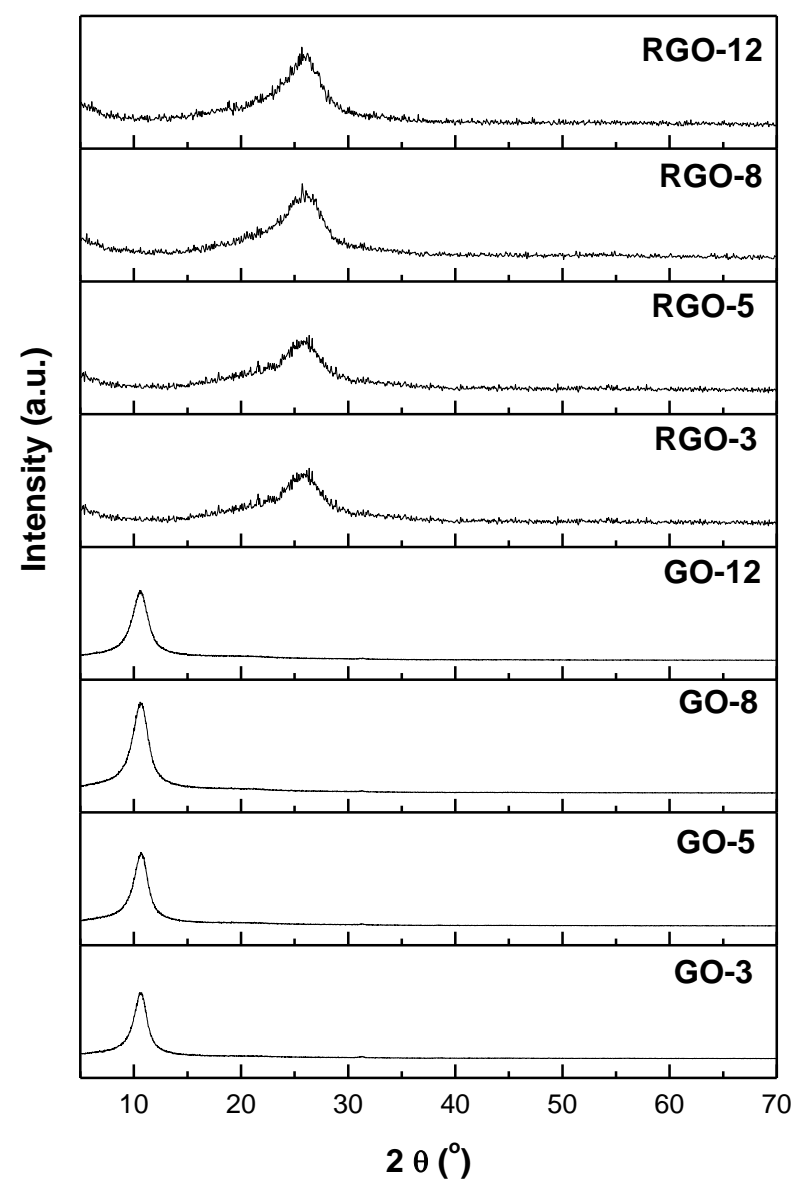

Figure 3. XRD diffractions of GO and RGO films.

\section{B. The Effect of Ultrasound Time on GO and RGO Film Thickness}

Representative bending and surface photographs of GO-3 film obtained by casting, taken with a camera, are given in Figure 4. As seen in Figure 4, GO-3 film has produced in large areas in accordance with the literature $[21,22,24,25]$ is elastic and can be bent. Also, all other films have shown the same behavior and are insulators.
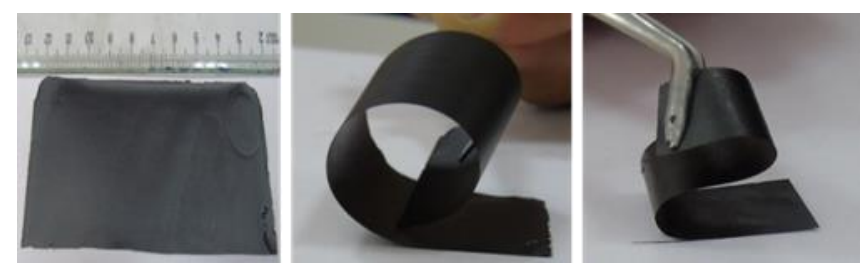

Figure 4. The bending and surface photographs of GO-3 film obtained by casting

GO films were thermally reduced to RGO at $1100^{\circ} \mathrm{C}$ in Argon gas flow. After the reduction of GO films, the distance between the layers has decreased due to the removal of oxygen-containing groups such as OH in GO's structure. Therefore, after thermal reduction, the film thickness was reduced. Figure 5 shows the bending and 


\begin{tabular}{|c|c|c|}
\hline & $\begin{array}{l}\text { BŞEÜ Fen Bilimleri Dergisi } \\
8(1), 345-355,2021\end{array}$ & $\begin{array}{r}\text { BSEU Journal of Science } \\
\text { https://doi.org/10.35193/bseufbd.900732 }\end{array}$ \\
\hline $\begin{array}{l}\text { BulLECCIKSEYH EDEBALL } \\
\text { ONIVERSITES }\end{array}$ & & 2458-7575 (https://dergipark.org.tr/tr/pub/bseufbd) \\
\hline
\end{tabular}

surface digital photographs of the RGO-3 film obtained as a result of the thermal reduction of GO-3 film. Just like GO films, graphene films have a bendable and elastic structure as seen in Figure 5.
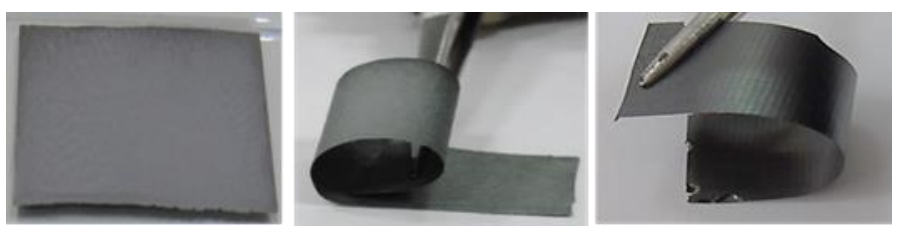

Figure 5. The Bending and surface digital photographs of RGO film, obtained with thermal reduction of GO-3 film.

GRO includes a number of layers like graphite whereas GO includes monolayers or small numbers of layers of oxidized graphite. The oxygenated functional groups in GRO causes of an positive effect for the exfoliation into monolayers of GO under ultrasound medium. As can be seen from Table 2, as the ultrasound time increased, the GO dispersion concentration increased due to the increasing of the degree of exfoliation of GO. In addition, GO films of the same thickness were obtained by casting method withused GO stock dispersions. As can be seen from Table 2, the average thickness of all GO films prepared is fixed as $21.5 \pm 3 \mu \mathrm{m}$. The reason why the study was designed in this way is that the change in film thickness affects the graphene properties [14]. By eliminating this effect, it was investigated how only the variation in ultrasound time changes the film properties.Figure 6shows the SEM images used to determine the cross-section morphologies and exfoliation degrees of GO and RGO films. As can be seen from Figure 6, all GO films have a layered structure, and after the GO films were thermally reduced, the distance between the layers have decreased and the exfoliation degrees increased.Although GO film thicknesses were almost same, RGO film thicknesses have increased with ultrasound time increasing from 3 to 8 hours and has decreased in the 12-hour ultrasound duration. The increase in RGO film thicknesses may be caused from the increase in the defect degree of GO with the increase in the ultrasound time and thus less frequently stacking of the layers.

Table 2. GO film codes and preparation conditions produced by casting GO dispersions at different concentrations.

\begin{tabular}{lcccc}
\hline \hline Name & $\begin{array}{c}\text { Ultrasound Time } \\
(\text { hours })\end{array}$ & $\begin{array}{c}\text { GO Concentration } \\
(\mathbf{m g} / \mathbf{m L})\end{array}$ & $\begin{array}{c}\text { GO Volume } \\
(\mathbf{m L})\end{array}$ & $\begin{array}{c}\text { Average GO } \\
\text { Film }\end{array}$ \\
\hline \hline GO-3 & 3 & 2.13 & 93.9 & 21.8 \\
\hline GO-5 & 5 & 2.78 & 60.0 & 21.6 \\
\hline GO-8 & 8 & 3.34 & 57.4 \\
\hline GO-12 & 12 & 4.49 & 21.5 \\
\hline
\end{tabular}




\begin{tabular}{|c|c|c|}
\hline & $\begin{array}{l}\text { BŞEÜ Fen Bilimleri Dergisi } \\
8(1), 345-355,2021\end{array}$ & $\begin{array}{r}\text { BSEU Journal of Science } \\
\text { https://doi.org/10.35193/bseufbd.900732 }\end{array}$ \\
\hline $\begin{array}{l}\text { BilECEKSEYHEDEBALI } \\
\text { ONIVERSITESI }\end{array}$ & & 2458-7575 (https://dergipark.org.tr/tr/pub/bseufbd) \\
\hline
\end{tabular}
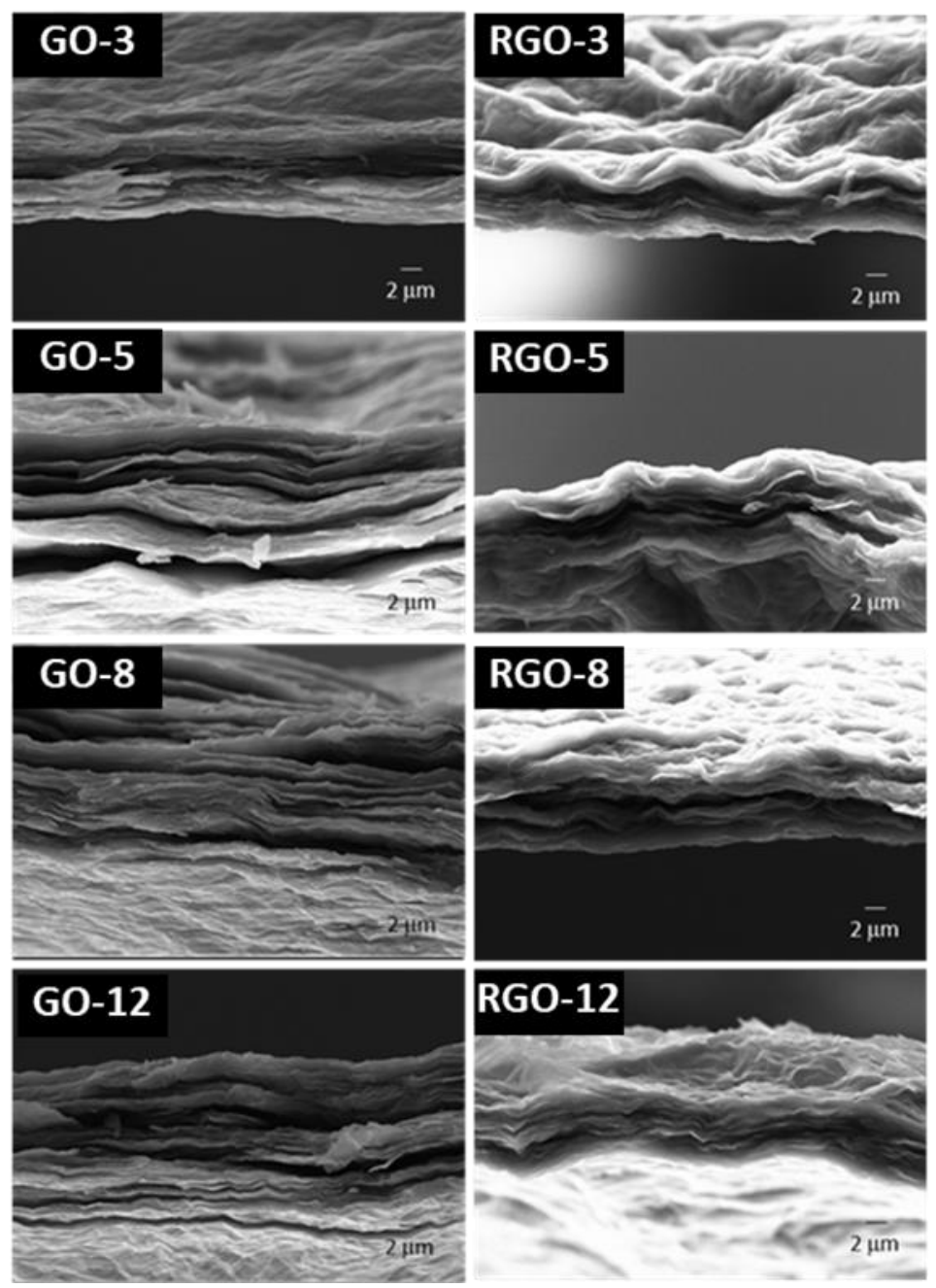

Figure 6. SEM images of GO and RGO films taken at 5000x magnification.

\section{The Effect on the Distance Between Layers of Ultrasound Time}

In Figure 7, there is a graph showing the change of the distance between layers calculated from Bragg's equation depending on the change in ultrasound time of GO and RGO films. As can be seen from the figure, the distance between the layers between GO films decreased up to 8 hours of ultrasound time depending on the increase in the ultrasound time, and it increased again in 12 hours by taking one turn in the 8 hour ultrasound time. However, in RGO films, this trend has progressed reversely and the distance between the layers is the highest in 8 hours of ultrasound time. For the same film thickness, the low distance between the layers causes the number of layers per unit thickness to be higher, and thus the exfoliation degree to be higher. As a result, while the highest degree of layering was obtained for 8 hours ultrasound times for GO films, it was obtained in 3 hours ultrasound time for RGO films. These results can be explained by the fact that although the exfoliation degrees of GO films increase with the increase of the ultrasound duration, they may have been subjected to structural deterioration and also by the exfoliation of the graphitic structures at $1100^{\circ} \mathrm{C}$ by thermal reduction. Also, according to distances between layers obtained from the XRD results in Table 1, the inter-layer distance values calculated from Bragg's equation support the SEM section morphologies. 


\begin{tabular}{|c|c|c|}
\hline & $\begin{array}{l}\text { BŞEÜ Fen Bilimleri Dergisi } \\
8(1), 345-355,2021\end{array}$ & $\begin{array}{r}\text { BSEU Journal of Science } \\
\text { https://doi.org/10.35193/bseufbd.900732 }\end{array}$ \\
\hline ERS & & 2458-7575 (https://dergipark.org.tr/tr/pub/bseufbd) \\
\hline
\end{tabular}

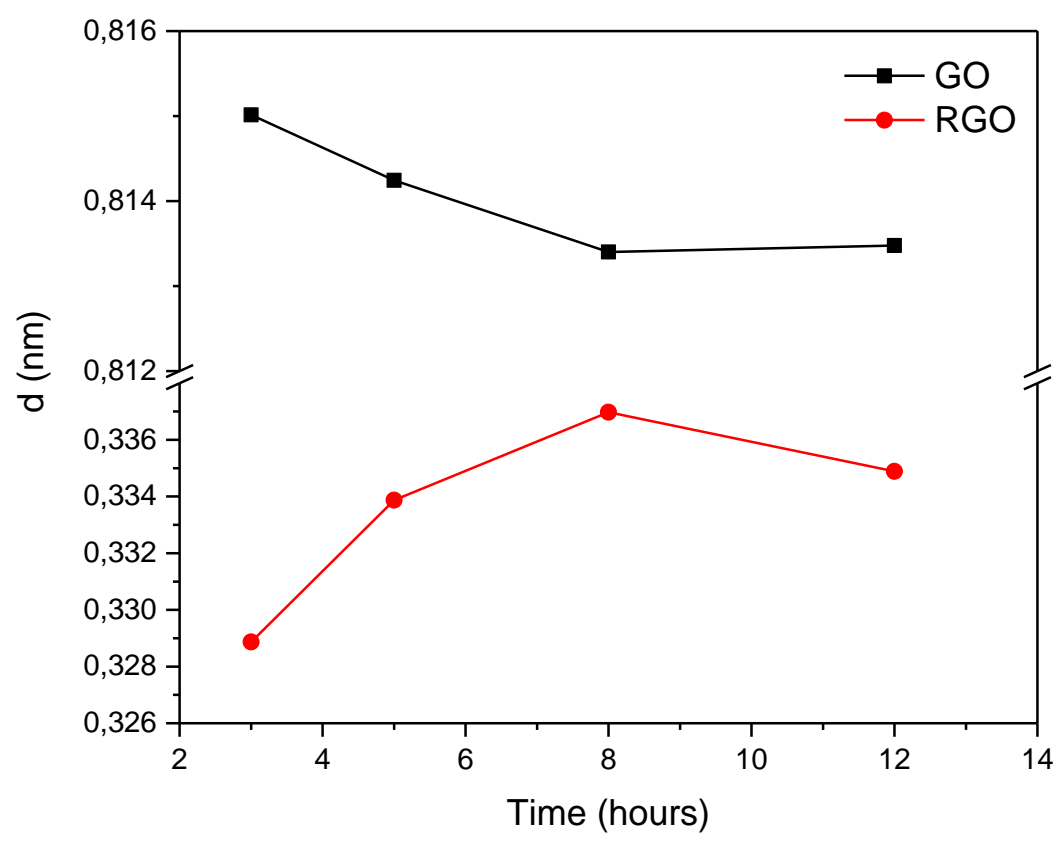

Figure 7. The variation of the distance between layers calculated from Bragg's equation depending on the change in ultrasound time of GO and RGO films.

\section{CONCLUSION}

In this study, preparation of GO dispersions from GRO at different ultrasound times, synthesis of GO films with the same film thickness by casting method, RGOfilm production as a result of thermal reduction of these films, and the GO and RGO films' XRD, FTIR, and SEM analyze results are presented. Depending on the increase in ultrasound time up to 8 hours, the exfoliation degree of GO films has gradually increased, while the degree of exfoliation has decreased in the ultrasound time of 12 hours. This situation has confirmed by the distance between the layers obtained from Bragg's equation and the SEM section images. For this reason, the optimum ultrasound time has been determined as 8 hours to produce GO films with a high degree of exfoliation. However, in RGOfilms obtained by thermal reduction at $1100{ }^{\circ} \mathrm{C}$ of GO films prepared from GO dispersions prepared in 3 , 5,8 , and 12 hours ultrasound times, the exfoliation degree has shown the opposite tendency compared to the results obtained than that of GO films. That is, the exfoliation degree of RGOfilms has decreased with the increase of ultrasound time up to 8 hours ultrasound time, and also has increased in 12 hours of ultrasound duration. Therefore, the highest exfoliation degree has been obtained in the RGO-3 film obtained by thermal reduction of GO films obtained from GO dispersions prepared in 3 hours of ultrasound time. The high degree of exfoliation is an important criterion for the production of RGOwith higher conductivity and better performance. For this reason, although GO dispersions prepared in low ultrasound times contain more graphitic structure, it can be possible to stratify these graphitic structures by thermal reduction. As a result, it has been determined that the parameters of ultrasound time and thermal reduction temperature are important for controlling the properties of RGOfilms produced by thermal reduction of GO films of the same thickness.

\section{ACKNOWLEDGMENT}

This work was supported by the BilecikŞeyh Edebali University Scientific Research Projects (BAP) fund within the scope of general-purpose projects (Project No: 2019-01.BŞEÜ.03-07).

\section{REFERENCES}

[1] Novoselov, K. S., Geim, A. K., Morozov, S. V., Jiang, D., Zhang, Y., Dubonos, S.V., Grigorieva, I.V. \& Firsov, A.A. (2004). Electric field effect in atomically thin carbon films. Science, 306, 666-669. 
[2] Li, D. \& Kaner, R.B. (2008). Graphene-based materials. Science, 320, 1170-1171.

[3] Zhao, N., Cheng, X. N., Yang, J., Yang, M. X., Zheng, S.H. \& Zhou, Y. Z. (2014). Experimental study on the preparation, characterization and conductivity improvement of reduced graphene-oxide papers. Journal of Physics and Chemistry of Solids, 75, 1141-1146.

[4] Geim, A. K. \& Novoselov, K. S. (2007). The rise of graphene. Nature Materials, 6, 183-191.

[5] Wang, H., Yuan, X., Wu, Y., Huang, H., Peng, X., Zeng, G., Zhong, H., Liang, J. \& Ren, M. M. (2013). Graphene-based materials Fabrication, characterization and application for the decontamination of waste water and waste gas and hydrogen storage/generation. Advances in Colloid and Interface Science, 195, 1940.

[6] Bai, H., Li, C. \& Shi, G. (2011). Functional composite materials based on chemically converted graphene. Advanced Materials, 23, 1089-1115.

[7] Hummers J. W. S. \& Offeman, R. E. (1958). Preparation of Graphitic Oxide. Journal of the American Chemical Society, 80,1958.

[8] Kovtyukhova, N. I., Ollivier, P. J., Martin, B. R., Mallouk, T. E., Chizhik, S. A., Buzaneva, E. V. \& Gorchinskiy, A. D. (1999). Layer-by-Layer Assembly of Ultra thin Composite Films from Micron-Sized Graphite Oxide Sheets and Polycations. Chemistry of Materials, 11, 771-778.

[9] Marcano, D. C., Kosynkin, D. V., Berlin, J. M., Sinitskii, A., Sun, Z., Slesarev, A., Alemany, L. B., Lu, W. \& Tour, J. M. (2010). Improved Synthesis of Graphene Oxide. ACS Nano, 4, 4806-4814.

[10] Botas, C., Alvarez, P., Blanco, P., Granda, M., Blanco, C., Santamaria, R., Romasanta, L. J., Verdejo, R., Lopez-Manchado, M. A. \& Menendez, R. (2013). Graphene materials with different structures prepared from the same graphite by the Hummers and Brodie methods. Carbon, 65, 156-164.

[11] Hirata, M., Gotou, T., Horiuchi, S., Fujiwara, M. \& Ohba, M. (2004). Thin-film particles of graphite oxide 1: High-yield synthesis and flexibility of the particles. Carbon, 42, 2929-2937.

[12] Wang, H., Robinson, J. T., Li, X. \& Dai, H. (2009). Solvo thermal reduction of chemically exfoliated graphene sheets. Journal of American Chemical Society, 131, 9910-9911.

[13] Paredes, J. I., Villar-Rodil, S., Martinez-Alonso, A. \& Tascon, J. M. D. (2008). Graphene Oxide Dispersions in Organic Solvents. Langmuir, 24, 10560-10564.

[14] Eda, G., Fanchini, G. \& Chhowalla, M. (2008). Large-area ultra thin films of reduced graphene oxide as a transparent and flexible electronic material. Nature Nanotechnology, 3, 270-274.

[15] Botas, C., Perez-Mas, A. M., Alvarez, P., Santamaria, R., Granda, M., Blanco, C. \& Menendez, R., (2013). Optimization of the size and yield of graphene oxide sheets in the exfoliation step. Carbon, 63, $562-592$.

[16] Si Y. \& Samulski, E. T. (2008). Synthesis of Water Soluble Graphene. Nano Letters, 8, 1679-1682, 2008.

[17] Hong J. Y. \& Jang, J. (2012). Highly stable, concentrated dispersions of graphene oxide sheets and their electro-responsive characteristics. Soft Matter, 8, 7348-7350.

[18] Valles, C., Young, R. J., Lomax, D. J. \& Kinloch, I. A. (2014). The rheological behaviour of concentrated dispersions of graphene oxide. Journal of Materials Science, 49, 6311-6320.

[19] Kim, K. S., Zhao, Y., Jang, H., Lee, S. Y., Kim, J. M., Kim, K. S., Ahn, J. H., Kim, P., Choi, J. Y. \& Hong, B. H. (2009). Large-scale pattern growth of graphene films for stretchable transparent electrodes, Nature, 457, 706-710.

[20] Liu, Z., Li, Z., Xu, Z., Xia, Z., Hu, X., Kou, L., Peng, L., Wei, Y. \& Gao, C. (2014). Wet-Spun Continuous Graphene Films. Chemistry of Materials, 26, 6786-6795.

[21] Li, X., Yang, T., Yang, Y., Zhu, J., Li, L., Alam, F. E., Li, X., Wang, K., Cheng, H., Lin, C. T., Fang, Y. \& Zhu, H. (2016). Large-Area Ultrathin Graphene Films by Single-Step Marangoni Self-Assembly for Highly Sensitive Strain Sensing Application. Advanced Functional Materials, 26, 1322-1329.

[22] Stankovich,S., Dikin, D. A., Piner, R. D., Kohlhaas, K. A., Kleinhammes, A., Jia, Y., Wu, Y., Nguyen, S. T. \& Ruoff, R. S. (2007). Synthesis of graphene-based nanosheets via chemical reduction of exfoliated graphite oxide. Carbon, 45, 1558-1565, 2007.

[23] Zhao, J., Pei, S., Ren, W., Gao, L. \& Cheng, H. M. (2010). Efficient Preparation of Large-Area Graphene Oxide Sheets for Transparent Conductive Films. ACS Nano, 4, 5245-5252.

[24] Bae, S. Y., Jeon, I. Y., Yang, J., Park, N., Shin, H. S., Park, S., Ruoff, R. S., Dai, L. \& Baek, J. B. (2011). Large-Area Graphene Films by Simple Solution Casting of Edge-Selectively Functionalized Graphite. ACS Nano, 5, 4974-4980.

[25] Cruz-Silva, R., Morelos-Gomez, A., Kim, H. I., Jang, H. K., Tristan, F., Vega-Diaz, S., Rajukumar, L. P., Elias, A. L., Perea-Lopez, N., Suhr, J., Endo, M. \& Terrones, M. (2014). Super-stretchable Graphene Oxide 
Macroscopic Fibers with Outstanding Knotability Fabricated by Dry Film Scrolling. ACS Nano, 8, 59595967.

[26] Yang, H., Cao, Y., He, J., Zhang, Y., Jin, B., Sun, J.L., Wang, Y. \& Zhao, Z. (2017). Highly conductive freestanding reduced graphene oxide thin films for fast photoelectric devices. Carbon, 115, 561-570.

[27] Dikin, D. A., Stankovich, S., Zimney, E. J., Piner, R. D., Dommett, G. H. B., Evmenenko, G., Nguyen, S. T. \& Ruoff, R. S. (2007). Preparation and characterization of graphene oxide paper. Nature, 448, 457-460.

[28] Ye, S., Chen, B. \& Feng, J. (2015). Fracture Mechanism and Toughness Optimization of Macroscopic Thick Graphene Oxide Film. Nature Scientific Reports, 5,13102-13112.

[29] Dreyer, D. R., Park, S., Bielawski, C. W. \& Ruoff, R. S. (2010). The chemistry of graphene oxide. Chemical Society Reviews, 39, 228-240.

[30] Dong, X. C., Wang, X., Wang, L., Song, H., Zhang, H., Huang, W. \& Chen, P. (2012). 3D Graphene Foam as a Monolithic and Macroporous Carbon Electrode for Electrochemical Sensing. ACS Applied Materials \& Interfaces, 4, 3129-3133.

[31] Qiu, H.J., Guan, Y.X., Luo, P. \& Wang, Y. (2017). Recent advance in fabricating monolithic 3D porous graphene and their applications in biosensing and biofuel cells. Biosensors and Bioelectronics, 89, 85-95.

[32] Chen, H., Muller, M. B., Gilmore, K. J., Wallace, G. G. \& Li, D. (2008). Mechanically Strong, Electrically Conductive, and Biocompatible Graphene Paper. Advanced Materials, 20, 3557-3561.

[33] Wang, C., Li, D., Too, C.O. \& Wallace, G.G. (2009). Electrochemical Properties of Graphene Paper Electrodes Used in Lithium Batteries. Chemistry of Materials, 21, 2604-2606.

[34] Liu, F., Song, S., Xue, D. \& Zhang, H. (2012). Folded Structured Graphene Paper for High Performance Electrode Materials. Advanced Materials, 24, 1089-1094.

[35] Wang, C., Wang, X., Wang, Y., Chen, J., Zhou, H. \& Huang, Y. (2015). Macroporous free-standing sulfur/reduced graphene oxide paper as cathode electrode for lithium-sulfur battery. Nano Energy, 11, 678686.

[36] Schniepp, H. C., Li, J. L., McAllister, M. J., Sai, H., Herrera-Alonso, M., Adamson, D.H., Prudhomme, R.K., Car, R., Saville, D.A. \& Aksay, I.A. (2006). Functionalized single graphene sheets derived from splitting graphite oxide. The Journal of Physical Chemistry C, 110, 8535-8539.

[37] Gonzalez, Z., Botas, C., Alvarez, P., Roldan, S., Blanco, C., Santamaria, R., Granda, M. \& Menendez, R. (2012). Thermally reduced graphite oxide as positive electrode in Vanadium redox flow batteries. Carbon, 50, 828-834.

[38] Botas, C., Alvarez, P., Blanco, C., Santamaria, R., Granda, M., Gutierrez, M. D., Rodrİguez-Reinoso, F. \& Menendez, R. (2013). Critical temperatures in the synthesis of graphene-like materials by thermal exfoliation-reduction of graphite oxide. Carbon, 52, 476-485.

[39] Pei S. \& Cheng, H. M. (2012). The reduction of graphene oxide. Carbon, 50, 3210-3228.

[40] Partoens, B. \& Peeters, F. M. (2006). From graphene to graphite: Electronic structure around the K point. Physical Review B, 74, 075404-1-11.

[41] Xu, M., Fujita, D., Gao, J. \& Hanagata, N. (2010). Auger Electron Spectroscopy: A Rational Method for Determining Thickness of Graphene Films. ACS Nano, 4, 2937-2945.

[42] Chen, X., Chen, X., Zhang, F., Yang, Z. \& Huang, S. (2013). One-pot hydrothermal synthesis of reduced graphene oxide/carbon nanotube/a- $\mathrm{Ni}(\mathrm{OH}) 2$ composites for high performance electrochemical supercapacitor. Journal of Power Sources, 243, 555-561.

[43] Zhang, J., Yang, H., Shen, G., Cheng, P., Zhang, J. \& Guo, S. (2010). Reduction of graphene oxide via Lascorbic acid. Chem.Commun., 46, 1112-1114. 